\title{
Livelihood And Life Experience Of Victims Of Human Trafficking In Mexico
}

\author{
Manuel R. Barragan Codina \\ Universidad Autónoma de Nuevo León, Mexico \\ Jose Juan Cervantes Niño \\ Universidad Autónoma de Nuevo León, Mexico \\ Arun Kumar Acharya \\ Sambalpur University, India
}

\begin{abstract}
The International Labor Organization estimated that $\mathbf{2 0 . 9}$ million or more individuals worldwide exploited for sex or labor or services through fraud, force or coercion. Nevertheless, the recent Global Slavery Index estimates nearly 46 million people subject to some form of modern slavery in the world today, which represents 0.6 percent of total world population. In the case of Mexico, every year thousands of young women and girls trafficked inside the country for the purpose of sexual exploitation and forced prostitution, often suffer extreme physical, sexual, and psychological exploitation, and it leads to a high risk of unwanted pregnancy and sexually transmitted infections. In this paper we have try to explore the livelihood and daily life experience of trafficked women in Mexico particularly in the case of Monterrey city. Our finding indicates that victims of sex trafficking forced to work all the day and longest period without allowing them to take rest. They also obligate to live in inhumane condition, and in most of the condition, they also do not allow to takes proper food. Moreover, they do not have medical access for any kinds of health problem. The same human is often over looked and pushed into insecure, unsafe and unhealthy working conditions.
\end{abstract}

\section{INTRODUCTION}

During the last twenty years, human trafficking has received attention all over the world both in political and public arena. Human trafficking or trafficking in persons and modern slavery terms are often use interchangeably to refer to a variety of crimes associated with economic exploitation of people (1). The International Labor Organization (ILO) (2) estimated that 20.9 million or more individuals worldwide exploited for sex or labor or services through fraud, force or coercion. Nevertheless, the recent Global Slavery Index estimates nearly 46 million people subject to some form of modern slavery in the world today (3), which represents 16 percent of total world population. In this regards, the International Labor Organization (ILO) indicates that worldwide women and girls account for the majority of labor trafficked victims, with 55 percent compared to 45 percent of men and boys, however, when takes into consideration sex trafficking women and girls accounts nearly 90 percent (2).

Human trafficking, which is known as modern day slavery, is the second largest illegal international trade, surpassed only by arms trafficking (4). In the year 2000, the United Nations in its Protocol to Prevent, Suppress, and Punish Trafficking in Persons adopted in Palermo defines human trafficking in Article 3 as:

the recruitment, transportation, transfer, harboring or receipt of persons, by means of threat or use offorce or other forms of coercion, of abduction, of fraud, of deception, of 
the abuse of power or of a position of vulnerability or of the having control over another person, for the purpose of exploitation (5).

This protocol cites a list of acts, which includes recruitment, transportation, and others, followed by the methods used to enforce those acts, for example threat, the use of force, or other abuses of power or of a position of vulnerability. The definition then relates to the motive: the purpose of exploitation. The definition continues by giving content to the term 'exploitation': 'Exploitation shall include, at a minimum, the exploitation of the prostitution of others or other forms of sexual exploitation, forced labor or services, slavery or practices similar to slavery, servitude or the removal of organs' (6).

The definition comprises three essential parts: recruitment, movement, and exploitation and all these points are key to explain the trafficking. Also, it is necessary to understand what is meant by coercion. The term coercion refers to threats of harm to or physical restraint against any person or intend to cause abuse or harm to a person. However, it is essential to consider other factors with regard to coercion in the case of sex trafficking. Technically, victims of human trafficking lived in slavery like situation $(1,7)$.

Research on trafficking of women states that young girls and women, mainly trafficked for the purpose of sexual exploitation and forced prostitution, often suffer extreme physical, sexual, and psychological exploitation, and it leads to a high risk of unwanted pregnancy and sexually transmitted infections (STIs) (8). Raphael and Shapiro (2004), for example, indicated that trafficked women suffer an extremely elevated physical and sexual violence. Their research in Chicago on trafficked women working as escorts, exotic dancers, and prostitutes on the street and in hotels reported that women suffered different kinds of violence, such as being threaten with a weapon, physically assaulted, stabbed, kidnapped, beaten with objects, and robbed.

It is a common fact that the victims of violence and sexual violence are overwhelmingly female. Studies on women trafficking pointed out that inequalities in distribution of power, authority and control between pimp and victim is main factor why these women remains subordinated (9). Dobash and Dobash (1979, in 10) argue that violence against these women creates notions of "keeping victims in her place". Thus, violence is a medium to dominate and suppress a trafficked woman. Some other researches indicates that trafficked women and commercial sex workers experience high levels of violence, including, but not limited to, physical assaults, sexual assaults, verbal threats, abuse, and psychological abuse (11).

Some other studies indicates that victims of sex trafficking forced to work all the day and longest period without allowing them to take rest. They also obligate to live in inhumane condition, and in most of the condition, they also do not allow to takes proper food. Moreover, they do not have medical access for any kinds of health problem. The same human is often over looked and pushed into insecure, unsafe and unhealthy working conditions. Thus, taking the above into account, I formulated the following research questions: how dose trafficked women maintain their livelihood, what kind of quality of life they leads?, What kind of events they experience in their daily life as a victim?. Considering the above question, the main objective of this paper is to explore the livelihood and daily life experience of trafficked women in Mexico. Using snowball method a total 10 women interviewed during 2016, to learn the causes and consequences of trafficking. All interviews followed the same topics in Spanish and audio taped. 


\section{Life experience of victims of trafficked women}

\section{RESULTS}

\section{Life of a trafficking victim working as a bar dancer: case of Berenice}

Berenice a 20 years old girl, never attended school, trafficked from Sinaloa state. When she was 12 years, she got pregnant and her parents forced to get marry her boyfriend and she describe: "my parents live in a community (indigenous) and believes that pregnancy before marriage is a pecado (sin). Thus, forcefully they organized my marriage before community people came to know about my pregnancy. Once we got married, my husband (named Jose) and myself moved to Mexico City where we stayed few days in Jose's aunt house. Few days later, Jose started working in an auto garage and once my baby born, I noted some changes in Jose's behaviors, he was avoiding me and after talking with him I came to know that he has an extramarital relationship. Soon after we divorced, I left Mexico City and returned to Sinaloa, but my parents were not interested to help me, even do not allow us to stay with them, so, I rented a small house in Culiacan (capital town of Sinaloa) and started working in a restaurant as a waiter.

Few months later, the owner of the restaurant offered me a job in Monterrey with a higher salary (around 10,000 pesos ( $\$ 600$ usd) per months), but he conditioned that I cannot take my child. I tried to convince my parents and finally I left my baby with them and weeks later with restaurant owner's brother Raul, we left for Monterrey. Once we reached Monterrey, we rented a hotel in downtown area. In the night, Raul came to my room and invited me for the dinner. We together went to a very nice restaurant called "Rey del Cabrito". Once we were there, he said this a famous restaurant for cabrito (goat meat) and said he has also invited some of other friends. In the meantime, others came; we were having some cerveza (beers). After sometime two men came and they greets me with kisses, which I did not like. Raul said: 'these people are your new boss, tomorrow on wards you will work with them'. We together had our dinner and later in the night, they left us in my hotel.

On the next morning when I woke up and went to Raul's room, he was not there, then I went to reception, I found those two persons. They asked me accompany them, I went them and they directly brought to this place (bar). When I asked them about my job, one of them said: Raul has sold you on 20,000 pesos with us and now you have work here as a bar dancer. When I argued that it is false and did not accept, they beat me and forced me to work. They said: if you want to go, give us our money and leave, but I said, I have not taken any money, again they beat me and threaten, if you escape from here we will kill, once you give our money you can leave this place.... And after that they forcefully they remove my cloth and put me in stage and obligate to dance with other girls. Once I was there, clients were touching my body.. some of them pulling my legs and kissing me forcefully.... I requested owner to whim they were calling padrino to leave in peace, but nobody was listing me, in fact everybody were laughing. After one hour they took me a room threaten to cooperate with them... if I will not obey or be obedient, they will kidnap my child, with this fear I started living here.

Every day, my work start at 4pm and it continue till 5 o' clock of the morning and some time it is 6or 7 am depends on week days and customers. Once I finish my job, padrino took us to the house, and then I sleep till 12 or $1 \mathrm{pm}$. After that, I take my food and bath, wash clothes and clean room with roommates and around 4pm padrino come for us and took us to bar. After reaching, I change my clothes, arranged chair, tables and clean glasses. When clients arrived, myself along with others offer them drinks and cigarettes and around 6pm we started dancing. In the meantime if any client ask for dance privately, I accompanied him.

Regarding sexual relationship, as it is a dancing bar in a very rare sex it happened. However, when clients ask for the private dance they asked us remove clothes and they puts forcefully 
touches our body parts. If a client ask for sex, we cannot say "no", in case I or other girls do not accept, padrino beat us and put fine. For example, since yesterday I have my mensuration and a client asked to sex during the private dance, I said at this moment not feeling good.... but he didn't understand my situation and complained to pimp, then he obligate me to have anal and oral sex with client.

On food, I think I eat less and drink more. My stomach is full on alcohol and smoke. Every day, I have to deal with different kinds of clients...,sometimes adolescents ages boys ask for sex, at that moment I do not what to answer, I feel very bad, because many of them are age of my brother... though I advised them not have sex, I afraid that they may caught with infection, however, they ignore my advice and forced to have sex... Every day I woke up with a hope that I may get free from this place but till now it has not happened... do not know when I will get my liberty.

\section{Life of a trafficking victim in prostitution: case of Rosy}

Rosy a 16 years old girls from the state of Puebla, trafficked to Monterrey three years before, she narrate: when I was 11 years old, my parents got separated, myself and my two sisters were living my mother. My mother was a working in city of Puebla as a domestic servant. Every week she was earning 500 pesos, which was not sufficient to maintain the family, thus she asked me to abandon my education and start working in central de abasto (central market). I was selling fruits, vegetables, and one day I met with a boy named Carols with whom later I had an emotional relationship. After six months, Carlos proposed me to marry him, buy could not accept as I was only 12 years old. Again, few months later he insisted to get marry, but when I consulted my mother, she didn't allow me. Thus, Carlos suggested me to escape together. He said: if we flee away from this place nobody will say anything and get marry peacefully.

Few weeks later it was Sunday, I was in Central de Abasto, Carlos came with bus ticket and asked me to accompany him. Together we came to bus terminal where travel to Monterrey. Nearly one day of journey we arrived Monterrey and stayed one night in a small hotel. Next day Carols went for the breakfast, and came with one of his friend. After having breakfast, we left hotel and shifted to Carlos's friend house, he was leaving in the municipality of Garcia. One week later, one day Carlos went with his friend to search a job and he didn't return home. Around 8 or 9 o' clock in the night Carlos's friend came, when I asked about Carlos, he said he is in delegación (police station) and asked accompany him. Immediately we took a taxi and went, nearly half an hour later, we reached to this place. But when I asked about Carlos he said he is inside, when I enter, I saw so many young girls and men were sitting. Due to light and music I was not able to listen or see properly and we sat in table.

Few minutes later, a person came to our table and Carlos's friend introduced me with him and said he is another friend of Carlos. I was not feeling safe with them, and tried to flee from there, but suddenly, they closed the door and a man came and forcefully took me to upstairs, though, I was shouting for help, nobody came to rescue me and they closed me in a small room. Next day a woman came, she said: yo te compre en 50,000 pesos, para que sea puta aqui, (I have bought you one 50,000 pesos from Carlos to work as a prostitute). Even she said Carlos work for her, supply young girls, and asked: eres virgin? (are you vergin?).... I didn't reply her, she pulled my hair and said: sorda no entiendes que te pregunto (deaf do not understand... what am I asking you...), I said never had relationship with anybody....then she congratulate me and said: reyena mañana te voy a estreñar con una cantidad importante (Princes tomorrow I am going to release you with a huge amount). I said I am not a commodity for you.. then angrily she said:"yes you are a commodity and I will use you as I wants". Next day she came with two young 
boys and forced me have sex with them, though, I requested them not to force, they did not listen in fact they obligate me to have sex and left me with bloody condition.

An hour later an old woman came took me to bathroom and asked to take bath... I was crying.. but nobody was looking to me or hearing me....Again, in the night two men came forced to have sex with them.... Though I was having sever pain, they did not listen me only asked to have sex with them...I realized that I cannot escape this place and if I will not obey these people they will harm me. Since those days I have totally surrender myself to them. They use me as their objects. Every day they coerce me to have sex with 12 to 15 clients... though I cannot resist, I have to do, as it has become a 'way of life' for me.

I start working nearly $6 \mathrm{pm}$ and it continue till next day early morning... sometime it go beyond that. Before clients go for sexual relationship most of the time they invite us to take alcohol with them, they paid for that....madrina has asked me charge each client 600 pesos for 30 minutes relationship... Regarding the sexual relationship, most of the clients asked for vaginal and oral sex, sometime they ask for anal sex... in case I said no... they beat me and some time they complain madrina on their dissatisfaction and in that case madrina scold us. If in a day three or four clients complain the same.. then she get furious and punish us severely; for example few weeks back one clients complain that I am not cooperating for anal sex, thus madrina locked me in a room and didn't provide food for half day and asked his boyfriend to masturbate on my face. I was feeling so ugly, but what can I do, it is my fault that I fall in love with Carlos. I guess my mother do not know where I am.. I also do not want to contact her, what I will tell her.. these people have destroyed my life. Last few days I am feeling so stress, thus started taking tacha (synthetic drug).. for few hours I feel good but after that again the same problem, so I am thinking to inject it through my vain.. my friends tells, it will give me more relax.. On other, madrina is very cruel with me, she never take us to hospital. When I feel bad in my health or any other girls she provides us medicine.. throughout the week she asked us to work.. never give a day to take rest. She has also ordered everybody that we have to please all clients... in case client will be unhappy think will go worst with us...

The experience of Berenice and Rosy how women lure through the false promises and later forced into trafficking network. Once women brought into brothel, they experienced long-term sexual abuse without access to minimum quality of life. In most of the cases, they live in inhumane conditions. As we observed in both the cases, trafficked women treated like objects more than once irrespective of their sentiments, opinions and body.

\section{CONCLUSION}

Trafficking of women and girls for sexual exploitation has become a significant and growing problem forthe global community. The costs to society include the degradation of human and women's rights, poor public health, disrupted communities, and diminished social development. Victims of trafficking acquire adverse physical, mental and social health conditions. The present study indicates that trafficking of women in Mexico multicausal factors. Every years thousands of teenage girls from the small towns and villages brought metro cities for the purpose of sexual exploitation. According to Human trafficking Report 2016, Mexico is source, transit and destination country for human trafficking. As it analyzed earlier, the major problem of human trafficking in Mexico is internal human slave trade. Once women and girls trapped with false promises by traffickers, they immediately shifted to brothel, which is a oneway entrance.

The analysis of life experience of Berenice and Rosy indicates for traffickers sentiments of victims never an important aspect, their only interest is to produce wealth on body of 
trafficked women. Inside the brothel, women lost control on their body and mind; it is padrino or madrina, who take all decision for victims. It can also analyzed and concluded that women experiences different kinds of violence in their daily life, they even do not know what to eat or drink. There is no specific hour for them to take rest. As Rosy said: "my life has become a life of smoke and alcohol".

On the other aspects, it can be learn from the two studies that; victims are living with higher amount of stress, thus, many of them have opted to consume different kinds of drugs, also victims experiences tense relationship with pimp, thus they also prefer to consume more alcohol and sometimes intensely they start fighting with other colleagues. Therefore, present study indicates that victims of human trafficking experience different of abuse, exploitation as well as there is higher control over their body in their day-to-day life. Some of them also suffered cruel treatment such as being locked into a dark room, forced sex, undressed and ordered to walk in fronts of clients.

\section{Reference}

Burke, Mary C. (2013).Human Trafficking: Interdisciplinary perspectives, Routledge, New York.

International Labour Organization (2012). ILO global estimate of forced labour: results and methodology, Special Action Programme to Combat Forced Labour (SAP-FL), Geneva.

Walk Free Foundation (2016), Global Slavery Index - 2016, www.globalslaveryindex.org

United States Department of State (USDS) (2016). The Trafficking in Persons Report-2016. U.S. Department of States, Washington DC. June.https://www.state.gov/j/tip/rls/tiprpt/

United Nations Office on Drugs and Crime (UNODC) (2004). United Nations Convention Against Transnational Organized Crime and The Protocols Thereto, United Nations Office on Drugs and Crime, Vienna. Accessed on 14/12/2015. http://www.unodc.org/documents/treaties/UNTOC/Publications/TOC\%20Convention/TOCebooke.pdf

Skilbrei, May-Len and Tveit, Marianne (2008). Defining Trafficking through Empirical Work: Blurred Boundaries and their Consequences, Gender, Technology and Development, vol.12(1).

Acharya, Arunkumar \& Bryson C. Jennifer (2014). Trafficking of women and vulnerability to HIV/STI infection in urban Mexico. Genus, 70 (2-3), DOI: 10.4402/genus-603.

Zimmerman, Cathy, Mazeda Hossain, Katherine Yun, Vasil Gajdadziev, Natalia Guzun, Maria Tchomarova, Rosa Angela Ciarrocchi, Anna Johansson, Anna Kefurtova, Stefania Scodanibbio, Maria Nenette Motus, Brenda Roche, Linda Morison \& Charlotte Watts (2008). The Health of Trafficked Women: A Survey of Women Entering Posttrafficking Services in Europe. American Journal of Public Health, 98(1).

Bimbi, F.,(2014). Symbolic violence: Reshaping post-patriarchal discourses on gender. Advances in Gender Research, 18-B, 275-301.

Barnard, M. (1993). Violence and vulnerability: Conditions of work for street working prostitutes. Sociology of Health and Illness, 15(5), 683-705.

Acharya, Arunkumar (2010). Feminization of Migration and Trafficking of Women in Mexico. Review of Research and Social Intervention, 30: 19-38. 